\title{
JULIÁN MEZA: DE ESPALDAS AL MAR Claudia Albarrán*
}

Para Julián Meza, que recientemente se jubiló del ITAM, después de haber dedicado más de treinta años a la enseñanza de la filosofía, la historia y la literatura.

Hace tres años, mi esposo, mi hija, una amiga y yo tuvimos la fortuna de viajar a Grecia con Julián Meza. Aunque nuestra amistad es muy antigua, nunca antes, en estos más de 25 años que llevamos de conocernos, habíamos planeado unas vacaciones juntos a lugares lejanos al D.F. La idea era ir a Atenas, un sitio en el que Julián ya había estado varias veces, y luego, embarcarnos rumbo a algunas islas griegas que él también había visitado años atrás. Yo suponía -ya que había insistido tanto en que lo acompañáramos- que una de las principales inquietudes de volver a Grecia una vez más era hospedarse algunos días en sus islas preferidas (cosa que las hordas de turistascrucero nunca pueden hacer), así como descubrir rutas alternativas que conectan islas pequeñísimas por las que los grandes navíos no suelen detenerse, pero que los antiguos griegos recorrían con frecuencia. Suponía, además, que otra de las prioridades de Julián (de allí su insistencia en que no hiciéramos los trayectos en avión, sino en distintos barcos) era disfrutar de las extraordinarias vistas del Mediterráneo; detenerse durante los largos recorridos a mirar las infinitas gamas de azules, de verdes, y gozar de la travesía desde la proa o desde la popa mientras conversaba con nosotros sobre el paisaje, bebiendo una buena botella de vino al aire libre.

No obstante, apenas abordábamos las pequeñas embarcaciones, Julián parecía obstinarse en contradecir todas mis suposiciones. Ascen-

* Departamento Académico de Lenguas, ITAM. 
día por las estrechas escalinatas del navío con prisa, como si temiera perder su lugar; comenzaba, luego, a bambolearse despacio entre los pasillos de un modo ridículamente infantil hasta encontrar el bar (generalmente situado en el corazón del barco) y, una vez allí -con un café o con una copa de vino en una mano y el acostumbrado Camel en la otra-, nos invitaba a acompañarlo haciendo una modesta señal.

Instalados a su lado, y siempre de espaldas al mar, Julián parecía olvidarse de todo lo que lo rodeaba, incluso de todo aquello que quedaba por venir, entreteniéndonos con los hilos de una deliciosa conversación en la que invocaba a sus dioses, justificaba las torpezas de su amigo Aquiles, acariciaba los cabellos rojizos de su amada Helena y lamentaba, con profundo dolor, la destrucción del único mundo que él ha admirado y respetado a lo largo de su vida: el mundo griego.

Conforme avanzaron los días y aumentaron los trayectos en barco, fui descubriendo, siempre de espaldas al mar, el vasto horizonte imaginario de Julián, su enorme capacidad para inventar mundos mejores, sus excepcionales recursos de orador, de conversador innato; esa fina inteligencia y esa cultura tantas veces amasada por él, decantada por infinidad de lecturas y de autores que, durante aquellos días inolvidables, puso al alcance de mí, de mi marido, de mi amiga y de mi hija adolescente,

112 como quien, despreocupadamente, riega alpiste a las palomas en una plaza cualquiera, en un gesto de infinita generosidad que sólo Julián sabe ofrecer en nombre de un territorio tan sagrado como privilegiado para él: la amistad.

No había sido, entonces, la experiencia de navegar por nuevas rutas la que lo había llevado a repetir una vez más ese viaje a Grecia. Justo él, que le tiene miedo al mar. Justo él, que en La huella del conejo y en La saga del conejo ha rendido sendos homenajes a navegantes y a piratas. Precisamente él, que nunca se ha puesto un traje de baño, que detesta las albercas y que jamás ha hecho el ridículo de sumergir ni media pantorrilla en el reventar de alguna ola inofensiva. No había sido tampoco el Mediterráneo ni sus estrechas callejuelas marinas las que lo habían invitado a volver allí. No había sido el oleaje ni sus colores ni los majestuosos atardeceres en altamar, que yo apenas alcancé a mirar durante las diferentes trayectorias desde alguna lejana claraboya, siempre atenta 
a su conversación. No. Lo que lo había llevado hasta allí era, simplemente, el arte de conversar con nosotros, sus amigos, $\mathrm{y}$, más aún, el placer de conversar sobre el principio, es decir, sobre los orígenes de Occidente.

Una vez de vuelta en México, caí en la cuenta de que ese exótico placer que habíamos tenido el gusto de compartir con él a lo largo de este viaje, no era nuevo en mi viejo amigo Julián, sino que había estado siempre en sus crónicas, en sus ensayos y, especialmente, en sus novelas. En La saga del conejo, Meza hace explícita esta inquietud ancestral de los hombres por narrar al apropiarse de un fragmento de Tabucchi que le sirve de epígrafe: “¿Dónde empieza una historia?”, se pregunta el escritor italiano. A lo que Julián no duda en contestar, en palabras del propio Tabucchi: "Las historias no empiezan, las historias suceden y no tienen un principio. $\mathrm{O}$ al menos ese principio no se ve, se escapa, porque estaba ya inscrito en otro principio, en otra historia, el principio es sólo la continuación de otro principio".

Publicadas por primera vez en 1991 y 1993, respectivamente, y reeditadas en un mismo volumen por el Fondo de Cultura Económica, La huella del conejo y La saga del conejo parecen partir de la voluntad de suceder por simple capricho, de la terquedad julianesca de contar una historia, por descabellada que ésta sea. Quizá para acercarnos al principio, quizá para alejarnos definitivamente de él; quizá, simplemente, por el capricho de conducirnos a otro lugar, de embarcarnos en una empresa imposible, de zambullirnos en otros océanos, de desembocar junto con él en otros continentes (llámense las áfricas occidentales, el cetáceo o Jascoyne), arrastrados por su imaginación y sin habernos movido de nuestro confortable asiento.

Y es que esta pregunta tan simple (“¿dónde comienza una historia?”). Es, creo yo, lo que a lo largo de todos estos años ha llevado a nuestro Meza a transitar neciamente por dos rutas paralelas, por dos caminos gemelos que, estoy segura, no cesará de recorrer hasta el día de su muerte: visitar Grecia y escribir; escribir y visitar Grecia, a sabiendas de que hacer una u otra cosa no es sino perseguir afanosamente la continuación de un mismo acto que fluye, se precipita y se muerde la cola sin que haya ni un principio ni un final. 
Hace ya varios años, cuando Julián me distinguió al invitarme a presentar La huella del conejo en el ITAM, dije que se trataba de una antinovela que narraba el antidescubrimiento emprendido por un antialmirante, cuya antinave encontraba un anticontinente habitado por seres monstruosamente imperfectos. Dije también que ese proyecto de Julián no podía leerse a la luz de los preceptos clásicos ni bajo la lupa de las formas tradicionales de escritura, porque su verdadera intención era liberarse de todas las reglas, romper los esquemas y subvertir los cánones de la Historia con mayúsculas, en un intento delirante por recuperar el significado de las palabras, por encontrar sus juegos, sus recovecos, sus ritmos secretos y sus relaciones ocultas.

Lo que dije entonces no sólo puede aplicarse a La huella del conejo, sino también a La saga del conejo, la segunda novela de Julián. Tanto los personajes como las aventuras que suceden en estas dos novelas no son más que pretextos, eslabones que establecen entre sí nexos fantasiosos e inimaginables, que sólo están allí para confundirse e incluso diluirse en una anécdota-océano que va desvaneciéndose conforme vamos leyendo para ceder su protagonismo al verdadero personaje de sus obras: el lenguaje.

Durante aquella presentación de La huella del conejo en el ITAM,

114 Luzelena Gutiérrez de Velasco acuñó el término "nao-novela" para describir la escritura de Julián; un neologismo que, si antes consideré pertinente, hoy me parece extraordinario para definir la experiencia que tiene el lector al transitar por las páginas de estas dos narraciones que, tanto por su título como por su contenido, parecen nutrirse de aguas semejantes, de ríos y corrientes similares que se permean y se entrecruzan entre sí en ese afán que tiene todo líquido de rebasar sus límites para evitar las fronteras que los constriñen.

Incluso me arriesgo a decir que las dos novelas fueron escritas con la intención exclusiva de "ser-como dice un personaje de La huella del conejo-el espacio inagotable de la imaginación" de su creador y constituyen una extravagante y alucinante fantasía, cuya fuerza radica en el poder lúdico de Julián Meza por conjurar las palabras.

Hoy sé que, a excepción de Grecia (adonde volverá una y otra vez hasta que se le acabe el aliento), a Julián Meza no le interesa trasportarse 
físicamente a otros rincones del mundo porque, como Ahasverus - personaje y cronista de La huella del conejo-, posee el don de la ubicuidad, que le permite aparecer y desaparecer a su antojo, inventar o parodiar la Historia a su placer, dejando tras de sí una estela de mentiras.

Hoy sé también que a Julián Meza le basta su imaginación, una pluma, una libreta o su computadora portátil para acomodarse felizmente en el mundo que él crea, de espaldas a esta realidad que detesta, que satiriza y de la que reniega en casi todas sus narraciones y ensayos, pero que nosotros, los seres humanos comunes y corrientes, solemos habitar sin tanto desagrado porque sabemos que, a la vuelta de la esquina, él volverá a regalarnos otro texto que, al divertirlo, nos divertirá también a nosotros.

No quisiera terminar estas páginas sin citar las palabras de mi hija Ana Pereira cuando, tras despedirnos de Julián en el aeropuerto de Atenas para continuar nuestro viaje rumbo a Constantinopla, comentó: "Yo no quisiera viajar sin Julián". A lo que yo solamente añadiría: "Yo no quisiera dejar de leerlo". 
CITAM Derechos Reservados.

La reproducción total o parcial de este artículo se podrá hacer si el ITAM otorga la autorización previamente por escrito.

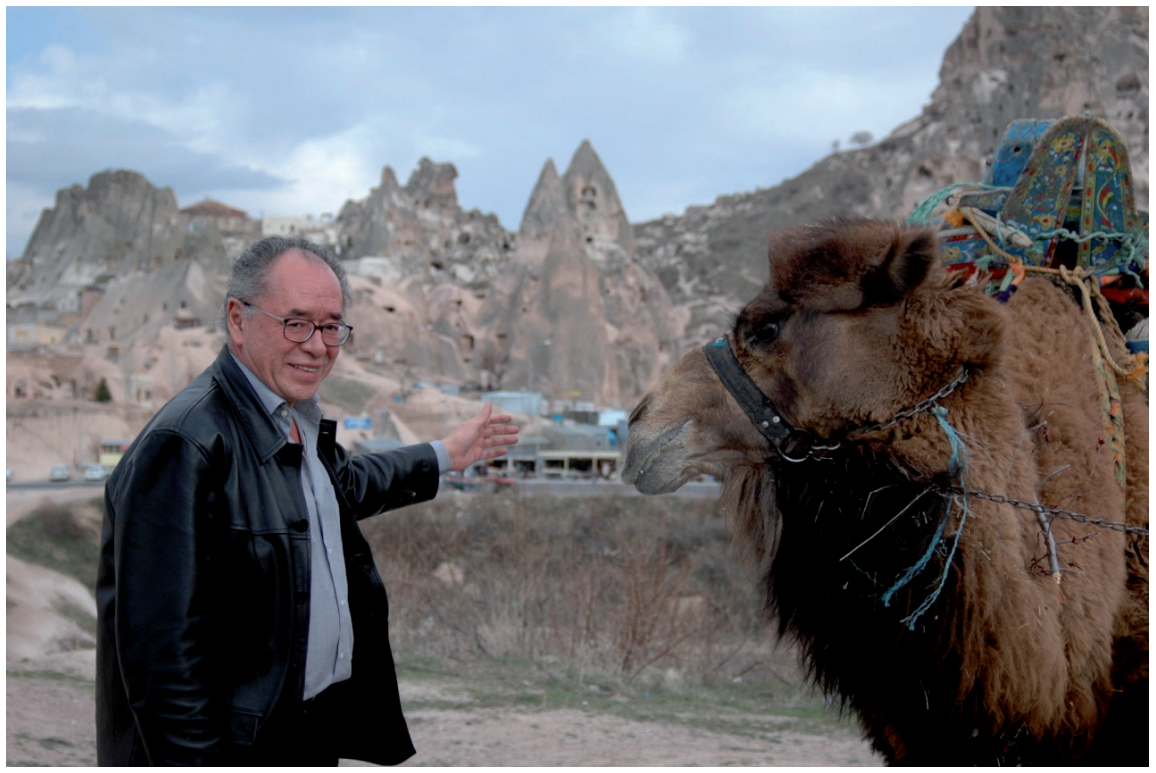

En Capadocia, 2005. 